\title{
An Overview of Marine Mammals in Eastern Indonesia 2016: Implications for Marine Mammals Research and Conservation
}

\author{
Ikha Jayanti Mamayu Utami ${ }^{1,2}$, Tri Retnaningsih Soeprobowati ${ }^{3,4}$, Denny Nugroho Sugianto ${ }^{5,6}$ \\ ${ }^{1}$ Master Student of Environmental Science,Diponegoro University, Semarang-Indonesia \\ ${ }^{2}$ Loka' (Regional Implementation Unit on Ministry of Marine and Fisheries Affairs) of Coastal and Marine Resource \\ Management, Sorong-Indonesia \\ ${ }^{3}$ School of Postgraduate Studies, Diponegoro University, Semarang-Indonesia \\ ${ }^{4}$ Department of Biology, Faculty of Science and Mathematics, Diponegoro University, Semarang-Indonesia \\ ${ }^{5}$ Department of Oceanography, Faculty of Fisheries and Marine Science, Diponegoro University, Semarang-Indonesia \\ ${ }^{6}$ Center for Coastal Disaster Mitigation and Rehabilitation Studies, Diponegoro University,Jl. Prof. Soedarto, SH. UNDIP, \\ Tembalang, Semarang, 50275 , Indonesia
}

\begin{abstract}
Eastern Indonesia is known as the center of marine biodiversity of the world as well as habitat and marine mammal migration path. Not all marine mammal events in eastern Indonesia are well documented. The purpose of this study was to determine the occurrence of marine mammals in eastern Indonesia in 2016. Data collection done through observation, indepth interview with the community and experts. The results of this study were 8 (eight) occurrences of marine mammals which were in Mollucas, North Mollucas and West Papua Provinces with the highest incidence in August. That marine mammals were Duyung (Dugong dugon), Sperm Whale (Physetermacrocephalus), Risso's Dolphin (Grampus griseus), and 2 types of unidentified Whales.The marine mammals exist were deliberately netted by people, stranded, trapped in fishing nets or deliberately commercialized. This marine mammals stranded occurence indicate the requirement of strategies development for handling these protected marine 'biota' to store their population.
\end{abstract}

Keywords: marine mammals; eastern Indonesia; conservation; Papua; Mollucas.

\section{Introduction}

Indonesiahas a variety of species of Cetacea but few records related to its spread, especially from remote areas[1]. The spread of Cetacean in Indonesian waters has not been known for certain yet because research on Cetacean is still very rare[2]. Information on distribution, population size and behavior of cetaceans is not widely known to the world[3]. Bird's Head Seascape located on Papua ineastern Indonesia is a global epicenter of marine biodiversity. Over 600 species of coral and 1,638 species of reef fish live there. Landscape area includes critical habitats for globallythreatened marine species including cetaceans. Short-term surveys and long-term observations indicate that the
Bird's Head Seascape is a hotspot for Cetacea and supports the continuity of the population of species entering the IUCN Red List [4]. Whales are known to migrate to breed in warmer tropical waters.Thedeepwater region of Mollucas is an important migration path for Whales from the Pacific Ocean to the Indian Ocean [5].

All types of Whales, Dolphins, and Dugongs in Indonesia have been established into protected aquatic biota including 35 Cetaceans and 1 Sirenia [6][7]. The International Union for Conservation of Nature and Natural Resources (IUCN ) categorizes the vulnerability status of certain marine mammalsglobal meaning that the status 
of vulnerability does not describe the situation inIndonesia but the world. Marine mammals are protected under The Minister of Forestry and Environment

NumberP.20/MENLHK/SETJEN/KUM.I/6/2018

Regarding the Types of Plants and Animals Protected[8].The International Trade EndangeredSpecies Convention (CITES)aimed at protecting plants and wildlife against the international trade of plant and wildlife specimens also establishes different levels of species protection. The existence of such protection because the trade of species is judged can lead to the sustainability of the species is threatened. The Government of Indonesiaratified CITES with Presidential Decree no. 43 of 1978[9].

\section{Materials and Methods}

\section{1 Location of the Study}

The study sites cover 4 provinces in eastern Indonesia, Mollucas, North Mollucas, Papua and West Papua (Fig. 1.).

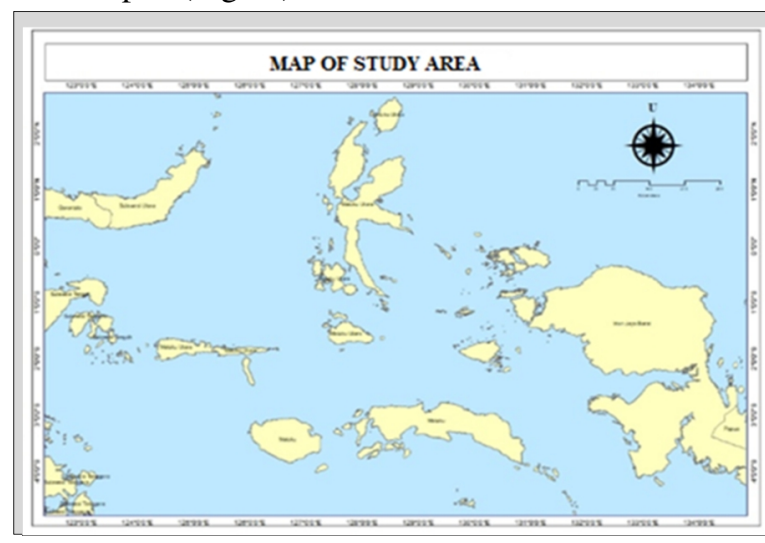

Fig. 1. Map of Study Area: Mollucas, North Mollucas, Papua and West Papua

\section{2 Data Collection}

The data collected were data on the incidence of stranded marine mammals. The incidence of marine mammals stranded within the scope of this study is that marine mammals found on shore or shallow waters in wounded, meshed, live or dead, powerless and have no ability to return to their natural habitat by their own efforts [10].

The data used are secondary data obtained from 'Loka PSPL Sorong' (Regional Implementation Unit for Management of Coastal and Marine Resources, Ministry of Marine Affairs and Fisheries ) obtained through field observation, interviews andinformation from the community, information and reports from stranded mammal networks and speciesidentification from experts.Data collectiontimeframe starts from January to December 2016.

\subsection{Data Analysis}

The data recorded are month of incidence, scientific name of species, number of individual, condition, location of stranded, and handling. Information on the location of marine mammal events is described using Arc Map 10.4 based on the coordinate points obtained to determine the spatial distribution of stranded marine mammal in Papua, West Papua, Mollucas, and North Mollucas in 2016.

\section{Results}

There are 8 stranded marine mammal in Mollucas, North Mollucas, and West Papua involved 9 individual, 5 individual stranded, 2 individualdeliberately arrested, 1 individual using spectacle and 1 individual trapped in Um Island (Table 1).

Dugong became the most commonly stranded marinemammals and consumed by the community. The most commonly found stranded Cetaceans were from theOdontoceti. The most commonoccurrence of stranded is in August. Visual spatial location of stranded marine mammals presented on Fig. 2. visual spatial condition of stranded marine mammals presented on Fig. 3, and photos of stranded marine mammal presented on Fig. 4.

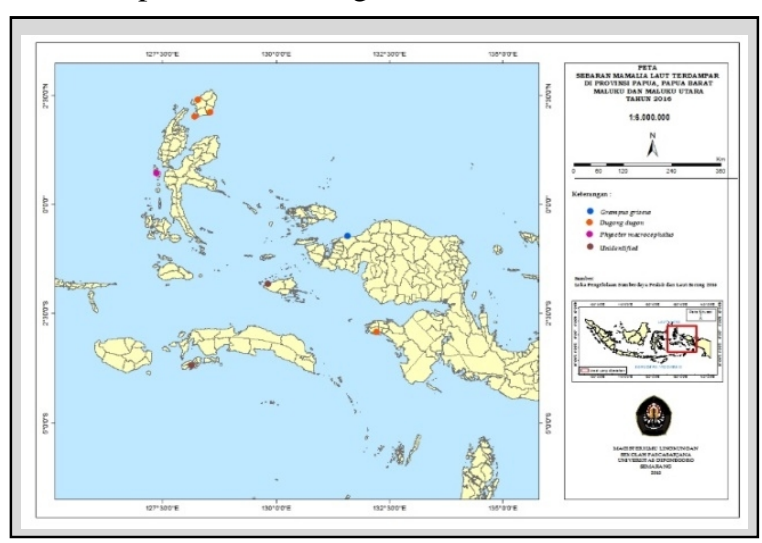

Fig.2.Location of Stranded Marine Mammal in Papua and Mollucas 2016

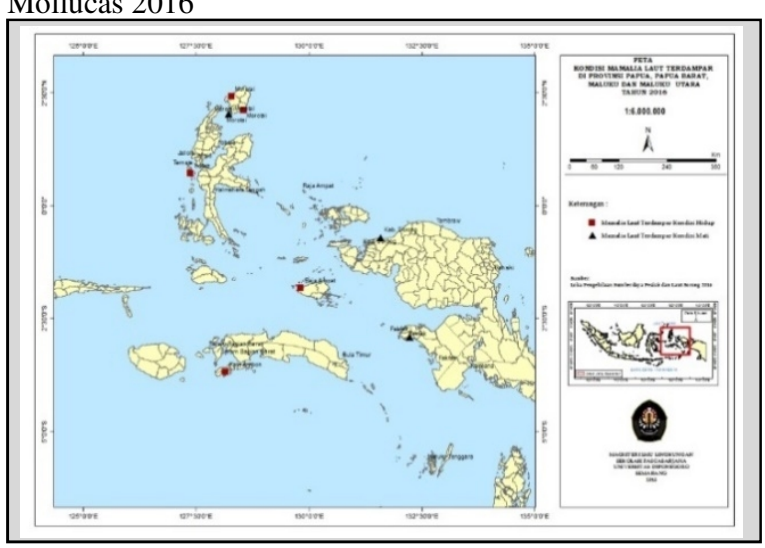

Fig.3.Condition of Stranded Marine Mammal in Papua and Mollucas 2016 
Table 1. Marine Mammal Information Stranded in Papua, West Papua, Mollucas and North Mollucas 2016

\begin{tabular}{|c|c|c|c|c|c|c|c|}
\hline Month & Order/Sub Order & Scientific Name & Number & Condition & Location & Province & Handling \\
\hline March & Sirenia & Dugong dugon & 2 & Alive & $\begin{array}{l}\text { Kokoya } \\
\text { Island }\end{array}$ & $\begin{array}{l}\text { North } \\
\text { Mollucas }\end{array}$ & Coaching \\
\hline April & - & Unidentified & 1 & Dead & Ambon & Mollucas & - \\
\hline July & Cetacea/Odontoceti & Grampus griseus & 1 & Alive & Um Island & West Papua & $\begin{array}{l}\text { Released to } \\
\text { the sea }\end{array}$ \\
\hline August & Sirenia & Dugong dugon & 1 & Alive & Fakfak & West Papua & Socialization \\
\hline August & Sirenia & Dugong dugon & 1 & Dead & $\begin{array}{l}\text { Sanggowo } \\
\text { Village }\end{array}$ & $\begin{array}{l}\text { North } \\
\text { Mollucas }\end{array}$ & Coaching \\
\hline August & Sirenia & Dugong dugon & 1 & Dead & $\begin{array}{l}\text { 'Cio Dalam' } \\
\text { Beach }\end{array}$ & $\begin{array}{l}\text { North } \\
\text { Mollucas }\end{array}$ & Buried \\
\hline Unidentified & - & Unidentified & 1 & Dead & Salfen & West Papua & - \\
\hline September & Cetacea/Odontoceti & Physeter macrocephalus & 1 & Dead & Ome Beach & $\begin{array}{l}\text { North } \\
\text { Mollucas }\end{array}$ & Swept away \\
\hline
\end{tabular}

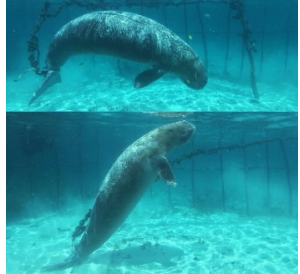

A

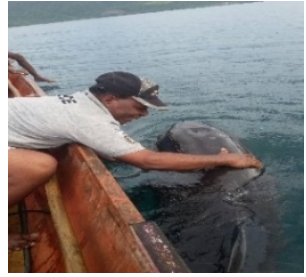

B

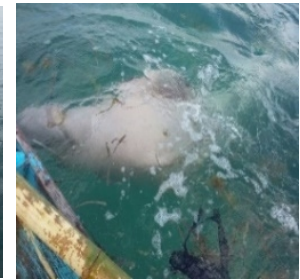

C

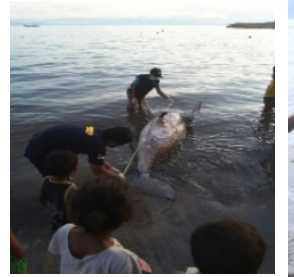

D

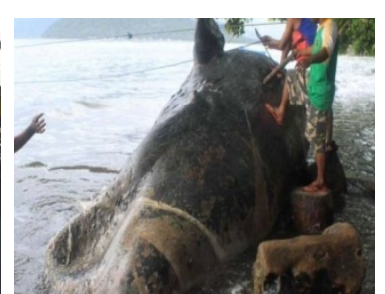

$E$

Fig. 4. Several photographs of marine mammal incident stranded (A) Dugongdugon were captured on Kokoya Island, Morotai Island District, North Mollucas Province on March 11, 2016 (B) Grampus griseus trapped on Um Island, Makbon District, Sorong District, West Papua Province July 25, 2016 (C) Dugong dugon commercialized

\section{Discussion}

This study provides information on the types and conditions of the diversity of Cetaceans and Sirenia found in eastern Indonesia along with the handling information that has been done.The population of Cetaceans in Indonesia is not known for certain, as few population surveys conducted [11] including for the Sirenian Order (Dugong dugong) can only be estimated by population distribution covering Sulawesi (Buton, Wakatobi, Bunaken, Takabonerate), NTT (Sumba, Lembata, Flores, Kupang Bay, Komodo Island), Mollucas (Aru, Lease Seram, Halmahera), Papua (Ujung Kulon, Cilacap, Cilegon, Labuhan, SegaraAnakan ) and Bali [12]. Surveys in eastern Indonesia were conducted in Bird's Head [1] and in 2011-2015 a survey of Cetacean and Sirenian presence in Raja Ampat [13] has been conducted. These studies have not produced estimates of population numbers only noted species diversity and potential threats to the population except Krebstudy of 35-55 individual Dolphins in the Mahakam [11].

Through predation in the depths of the ocean and its excretion, Sperm Whale stimulates the entry of carbon into the deep sea, Whales removes $2 \times 10^{5}$ tons more carbon from the atmosphere than they add during the respiration process. The whale population

in Kiat, West Fakfak District, FakfakRegency, West Papua on August 23, 2016 (D) Dugong dugon stranded on CioDalam Beach, Morotai Island District on August 30, 2016 (E) Physetermacrocephalus stranded on Ome Beach, Tidore City, North Mollucas Provinceon September 26, 2016

acts as a carbon sink [14].Likewise with Sirenia who has a reciprocal relationship with the existence of Seagrass Habitat. Seagrass is an important carbon storage. This system is known as blue carbon. The mechanism ofblue carbon starts when carbon is absorbed by coastal vegetation which is then transferred and stored in parts of plants and sediments. Carbon absorption can occur through photosynthetic processes of phytoplankton and carbon stored in deep sea sediments. 1 ha of Seagrasswith small biomass, can store carbon comparable to 1 to 2 hectares of sub tropical forest [15].

\section{Summary}

Indirectly, maintaining the presence of marine mammal populations and their habitat can help reduce carbon emissions globally. The data of stranded marine mammal is expected to provide additional information for research, population estimates, distribution, specific species in eastern Indonesia, marine mammal conservation planning in Indonesia and as a basis for more comprehensive study.

Thanks to 'Loka PSPL Sorong' (Regional Implementation Unit formManagement of Coastal and Marine Resources, Ministry of Marine Affairs and Fisheries ) who has provided information support this paper. 


\section{References}

1. A. I. Ender, Muhajir, S. Mangubhai, J. R. Wilson, Purwanto, and A. Muljadi, CetaceansIn The Global Centre OfMarine Biodiversity, Mar. Biodivers. Rec.,7, 1-9 (2014)

2. D. Salim, Konservasi Mamalia Laut (Cetacea) di Perairan Laut Sawu Nusa Tenggara Timur, J. Kelautan , 4, 24-41 (2011)

3. K. MacLeod, M. P. Simmonds, and Murray E, Abundance of Fin (Balaenoptera physalus) and Sei Whales (Balaenoptera orealis) Amid Oil Exploration and Development Off Northwest Scotland,J. Cetacean Res. Manag.,8,247-254 (2006)

4. S. Mangubhai, M. V. Erdmann, J. R. Wilson, C. L. Huffard, F. Ballamu, N. I. Hidayat, C. Hitipeuw, M. E. Lazuardi, Muhajir, D. Pada, G. Purba, C. Rotinsulu, L. Rumetna, K. Sumolang, W. Wen, Papua Bird's Head Seascape:Emerging Threats and Challenges In The Global Center Of Marine Biodiversity, J. Marpolbul, 64, 2279-2295 (2012)

5. K. A. Monk, Y. D. Fretes, and G. R Lilley, Ekologi Nusa Tenggara dan Maluku, Jakarta: Prenhallindo, (2000)

6. P. Rudolph, C. Smeenk, and S. Leatherwood, Preliminary Checklist of Cetacea in the Indonesian Archipelago and Adjacent Waters . Zoologische Verhandelingen, 312, 3-24 (1997)

7. D. Kreb, P. L. K. Mustika, B. Kahn, A. Yanuar, and Muhajir, National reviews of status, research, catch, by-catch, conservation, and legislation of marine mammals in Indonesia: a country report to the 3rd Southeast Asian Marine Mammal Symposium Langkawi, 3rd Southeast Asian Marine Mammal Symposium (2013)

8. Menteri Lingkungan Hidup dan KehutananRepublikIndonesia.

Peraturan Menteri Lingkungan Hidup Dan Kehutanan Republik Indonesia

Nomor P.20/MENLHK/SETJEN/KUM.1/6/2018Te ntang Jenis Tumbuhan Dan Satwa Yang Dilindungi, Berita Negara Republik Indonesia Tahun 2018 Nomor 880, Jakarta: Dirjen Peraturan Perundang-Undangan Kemenkumham Republik Indonesia, (2018)
9. Republik Indonesia, Keputusan Presiden Republik Indonesia No 43 Tahun 1978 Tentang Mengesahkan Convention on International Trade in Endangered Species of Wild Fauna and Flora yang telahditandatangani di Washington pada Tanggal 3 Maret 1973, Lembaran Negara Republik Indonesia Tahun 1978 Nomor 51, Jakarta: Sekretariat Negara RI (1978)

10. K. M. Moore, C. A. Simeone, and R. L. Brownell Jr, Strandings, Encycl. Mar. Mamm, 945-951 (2018)

11. P. L. K. Mustika, D. Sadili, A. Sunuddin, D. Kreb, Sarmintohadi, I. Ramli, D. Suprapti, J. Ratha, E. Lazuardi, H. Rasdiana, Y. Miasto, R. P. Sari, S. Annisa, N. Terry, M. M. P. Monintja, Rencana Aksi Nasional Konservasi Cetacea Indonesia Periode I: 2016-2020, Jakarta: Dit. KKHL, Ditjen Pengeloaan Ruang Laut, KKP (2015)

12. M. H. Hutomo, D. Longh, W. Kiswara, and M. Moraal, Strategi dan Rencana Aksi Konservasi Dugong di Indonesia. Jakarta: Pusat Penelitian Oseanografi-LIPI Jakarta dan Institute of Environmental Science Leiden, (2011)

13. B. Kahn, Marine Mammals of Raja Ampat (Northern Waters), Papua Barat, Indonesia: Species Diversity for 20112015 , 9-10 (2015)

14. T. J. Lavery,B. Roudnew, P. Gill, J. Seymour, L. Seuront, G. Johnson, J. G. Mitchell, V. Smetacek, IronDefecationBySpermWhalesStimulatesC arbonExport inthe SouthernOcean.Proc. R. Soc. B,doi: 10.1098/rspb.2010.0863, 3527-3531 (2010).

15. The Nature Conservancy, Blue Carbon,PenyimpanKarbon di Daerah PesisirLaut, Nature (2018), [Online]. Available: https://www.nature.or.id/ruangmedia/berita-terbaru/blue-carbonpenyimpan-karbon-di-daerah-pesisirlaut.xml 